\begin{tabular}{l|lll}
\hline History Article & Received: February 2020 & Approved: February 2020 & Published: February 2020 \\
\hline
\end{tabular}

\title{
ANALISIS URGENSI PENGEMBANGAN KOMIK DIGITAL DENGAN MENGINTEGRASIKAN NILAI-NILAI KEISLAMAN
}

\author{
Felzia Raneza ${ }^{1}$, Hening Widowati ${ }^{2}$ \\ ${ }^{1,2}$ Program Studi Pendidikan Biologi, Pascasarjana Universitas Muhammadiyah Metro \\ e-mail : felzia.m2m@gmail.com ${ }^{1}, \underline{\text { hwummetro@gmail.com }}{ }^{2}$
}

\begin{abstract}
Abstrak: Di era modern teknologi industri 4.0, pendidik diminta untuk mampu mengembangkan kemampuan membuat media pembelajaran yang akan digunakan dengan menggunakan bantuan teknologi. Komik cukup populer diantara remaja termasuk siswa di jenjang SMA. Salah satu tipe komik adalah komik digital, sebelymnya sudah menjadi tren global, yang berguna sebagai media pembelajaran yang efektif. Untuk mengambil keuntungan dari kesempatan besar ini, studi ini bertujuan untuk menganalisis pentingnya pengembangan komik digital. Pembuatan komik digital ini menggunakan model 4D yang merupakan model pengembangan yang terdiri dari 4 tahapan.
\end{abstract}

Kata kunci : komik digital, media belajar, nilai-nilai keislaman

\begin{abstract}
In the era of modern industrial technology 4.0, educators are required to be able to develop skills in making learning media that will be used with the help of technology. Comics are popular among teenagers where high school students are included. One type of comics, digital comics, has recently become a global trend, which is useful for use as an effective learning medium. To take advantage of this great opportunity, this study aims to analyze the importance of developing digital comics. The making of this digital comic uses the $4 D$ model which is a development model that consists of 4 stages.
\end{abstract}

Keyword : Digital comic, learning media, islamic value

\section{How to Cite}

Raneza, Felzia dan Hening Widowati. 2020. Analisis Urgensi Pengembangan Komik Digital Dengan Mengintegrasikan Nilai-Nilai Keislaman. Biolova 1(1). 15-20. 
Perkembangan ilmu pengetahuan dan teknologi hingga zaman modern era 4.0 ini semakin mendorong upaya-upaya pembaharuan pengetahuan. Perkembangan dalam pendidikan dapat dilihat dari berbagai pembaharuan kurikulum dan kualitas pendidik. Untuk mencapai tujuan pembelajaran yang diharapkan, pendidik juga diharuskan untuk dapat mengembangkan keterampilan membuat media pembelajaran yang akan digunakan. Hal ini memperkaya sumber belajar seperti komik yang akan digunakan pendidik untuk berinteraksi dengan peserta didik saat proses pembelajaran berlangsung, salah satunya dalam proses pembelajaran biologi

Peran pendidik tidak terlepas dari bahan ajar. Proses pembelajaran akan berjalan secara efektif dan efesien jika tersedia media pembelajaran yang berkualitas. Komik merupakan salah satu bentuk inovasi media pembelajaran yang dapat digunakan dalam proses pembelajaran. Komik dapat diartikan sebagai salah satu media pembelajaran yang disusun dengan tampilan yang menarik dengan penggunaan bahasa yang mudah dipahami untuk membantu peserta mencapai suatu tujuan pembelajaran. Hal ini menunjukkan begitu pentingnya media dalam proses pembelajaran.

Berdasarkan hasil wawancara dengan pendidik dan beberapa siswa pada tanggal 21 Oktober 2019 di MAN 1 Metro diperoleh data sebagai berikut; 1) proses pembelajaran di MAN 1 Metro masih menggunakan buku paket dan LKS, 2) belum pernah dikembangkan media pembelajaran berupa komik digital oleh guru atau peneliti lainnya yang digunakan di kelas $\mathrm{X}, 3)$ penggunaan media dalam proses pembelajaran masih klasik, 4) guru masih belum memiliki media pembelajaran yang di dalamnya terdapat nilai-nilai keislaman khususnya mata pelajaran biologi, 5) serta dalam proses pembelajaran guru masih jarang menghubungkan materi dengan nilai-nilai keislaman. Latar belakang MAN 1 Metro yang berbasis islami seharusnya memiliki bahan ajar yang terintegrasi oleh Al-Qur'an dan Hadist khususnya mata pelajaran biologi.

Berdasarkan permasalahan di atas maka peneliti mengembangkan komik digital dengan mengintegrasikan nilai-nilai keislaman sebagai media pembelajaran biologi pada materi ruang lingkup biologi. Peneliti mengembangkan komik digital sebagai media pembelajaran dengan kemasan yang menarik, sehingga diharapkan dengan komik digital ini dapat meningkatkan minat belajar siswa, dan dengan mengintegrasikan nilai-nilai keislaman di dalam uraian materi baik di awal sub materi dan di akhir materi yang bersumber dari AlQur'an dan Hadist, harapannya guna terciptanya siswa yang unggul dalam prestasi serta akhlak.

Berdasarkan rumusan masalah di atas, tujuan penelitian pengembangan yaitu untuk menghasilkan produk berupa komik digital dengan mengintegrasikan nilainilai keislaman sebagai media pembelajaran biologi pada materi ruang lingkup biologi yang layak. Mengatasi permasalahan serta memenuhi kebutuhan yang ada dengan media pembelajaran berupa komik digital yang valid sehingga dapat digunakan sebagai pendukung sarana dan prasana proses pembelajaran.

Menurut Karwono (2012:140) bahwa: Sumber belajar mempunyai peran yang sangat erat dengan pembelajaran yang dilakukan, dan pola pola yang dilakukan oleh guru. Sumber belajar adalah segala sesuatu dan dengan mana seseorang mempelajari 
sesuatu. Sumber belajar meliputi: pesan orang bahan alat, teknik dan latar. Sumber belajar dapat dibedakan menjadi sumber belajar yang didesain dan sumber belajar yang dimanfaatkan. Pemanfaatan sumber belajar, guru mempunyai tanggung jawab membantu peserta didik agar belajar lebih mudah, lebih lancar, lebih terarah. Pendidik dituntut untuk memiliki kemampuan khusus yang berhubungan dengan pemanfaatan sumber belajar.

Bahan ajar dapat digunakan dan dikembangkan oleh seorang guru dalam pemanfaatan sumber belajar. Sumber belajar yang dapat digunakan oleh guru di antaranya adalah dengan menggunakan komik digital. Komik merupakan suatu media pembelajaran yang dipandang lebih efektif untuk mengajarkan dan mengembangkan kreativitas siswa. Kita ketahui bahwa tidak jarang buku-buku yang digunakan sekarang lebih banyak berupa textbook, sehingganya belum memberikan pengaruh terhadap minat baca peserta didik. Minat membaca yang rendah menyebabkan keaktifan dan hasil belajar menjadi rendah. Kerumitan bahan ajar yang disampaikan semakin membuat peserta didik kurang tertarik untuk membaca buku pelajaran termasuk buku biologi. Peserta didik cenderung tertarik membaca buku cerita bergambar (seperti komik) dibandingkan buku pelajaran, dikarenakan komik memiliki alur cerita yang runtut dan teratur memudahkan untuk diingat kembali.

Menurut Herawati, dkk (2014:74) menyatakan bahwa: Komik merupakan suatu bentuk bacaan dimana siswa akan membacanya tanpa dibujuk karena tampilannya yang menarik sehingga meningkatkan minat baca. Selain itu, kerumitan bahan ajar yang akan disampaikan dapat disederhanakan dengan bantuan media pembelajaran dalam bentuk komik.
Lamb \& Johnson (dalam Sudiyanto, 2017) menyatakan bahwa: Perkembangan teknologi dapat dikombinasikan dengan keunggulan komik untuk menghasilkan media pembelajaran yang bermanfaat bagi siswa. Salah satunya dengan media komik digital. Komik digital merupakan komik sederhana yang disajikan dalam media elektronik tertentu. Komik digital juga dapat didefinisikan sebagai komik yang diterbitkan/disajikan dalam website, webcomics, online comics, atau internet comics

Rusman

(2017:214)

berpendapat bahwa: Media pembelajaran merupakan suatu teknologi pembawa pesan yang digunakan untuk keperluan pembelajaran; media pembelajaran merupakan sarana fisik untuk menyampaikan materi pembelajaran. Media pembelajaran merupakan sarana komunikasi dalam bentuk cetak maupun pandang dengar termasuk teknologi perangkat keras.

Muspiroh (2013:489) yang menyatakan bahwa: Integrasi nilainilai islam dalam pembelajaran sains akan memberikan kekuatan pada ranah afektif, psikomotor dan kognitif. Diimplementasikan dalam pembelajaran di sekolah, akan memberikan hasil belajar yang mencakup dalam semua ranah belajarnya. Memberikan warna yang berbeda yang selama ini banyak terjadi ranah kognitif begitu dominan atau bahkan menjadi satu-satunya yang dikembangkan dalam pembelajaran.

\section{METODE}

Penelitian yang dilakukan yaitu penelitian pengembangan, adapun yang dikembangkan berupa media pembelajaran berupa komik digital. Prosedur yang dilakukan oleh peneliti dalam mengembangkan komik digital ini yaitu sesuai dengan model 
pengembangan seperti yang disarankan oleh Thiagarajan dan Semmel (dalam Trianto, 2011:189) adalah Model 4-D. Model ini terdiri dari 4 tahap pengembangan, yaitu Define, Design, Develop, dan Desseminate. Langkahlangkah mengembangkan Modulini yaitu:

Define (Pendefinisian)

Tahap ini yang dilakukan yaitu untuk melakukan pra survey yang terdiri dari proses observasi dan wawancara, dengan melihat masalah dan menganalisis kebutuhan media yang ada di sekolah MAN 1 Metro. Wawancara dilakukan oleh peneliti terhadap guru dan beberapa peserta didik kelas X IPA di MAN 1 Metro.

\section{HASIL}

Berdasarkan hasil wawancara di atas maka dilakukannya analisis pentingnya pengembangan komik digital ini mengenai media yang digunakan dalam proses pembelajaran khususnya mata pelajaran biologi, yaitu sebagai berikut: 1) perlunya media penunjang dalam proses pembelajaran, 2) perlunya pengembangan media komik digital yang sesuai dengan perkembangan ilmu dan teknologi modern, 3) pengembangan media berupa komik digital ini sudah berkemajuan, di mana dalam penggunaanya nanti lebih memudahkan peserta didik karena dapat di simpan dalam gadget maupun laptop, 4) komik digital ini nantinya akan berintegrasi nilai-nilai keislaman yang bersumber dari Al-qur'an dan hadist, 5) komik digital ini nantinya diharapkan dapat memenuhi kebutuhan sekolah dalam proses pembelajaran sebagai media penunjang yang memiliki teknologi berkemajuan serta terintegrasinnya nilai-nilai spiritual.

Berdasarkan hasil analisis di atas, maka perlu dikembangkan media komik digital biologi dengan mengintegrasikan

nilai-nilai

keislaman.

\section{PEMBAHASAN}

Berdasarkan analisis kebutuhan hampir seluruh responden mengenal dan pernah membaca komik. Meskipun mayoritas responden membaca komik hanya dalam bentuk buku dan sebagian pernah membaca komik digital melalui gadget. Alasan terbanyak responden adalah harga buku komik yang relatif mahal. Hal ini sesuai dengan pernyataan Nurinayati, dkk (2014) yang menyatakan bahwa komik digital saat ini semakin popular karena kemudahan akses dan biaya produksi yang lebih murah. Karena sifatnya yang popular, selain sebagai hiburan, akan lebih baik jika media tersebut dapat dijadikan sarana untuk pembelajaran siswa. Meskipun masih ada sebagian responden yang belum terbiasa membaca komik digital, sifat remaja yang selalu ingin tahu justru membuat media pembelajaran komik digital sebagai hal yang baru dan menarik bagi remaja.

Komik digital ini telah dirancang agar dapat memenuhi kebutuhan proses pembelajaran dan membantu peserta didik dalam memahami serta mengekspor materi pembelajaran yang telah diberikan oleh guru. Komik digital yang dikembangkan didesain tidak hanya menyajikan teori dan latihan saja atau segi kognitifnya saja melainkan mampu membimbing peserta didik menggunakan bahasa sehari-hari, sehingga peserta didik dapat dengan cepat memahami isi dari komik, hal ini didukung dengan pendapat yang dikemukakan oleh Wardani (2012:231), kelebihan dari komik yaitu: a) Menggunakan bahasa seharihari, sehingga siswa dapat dengan cepat memahami isi dari komik, b) Menggunakan gambar-gambar yang 
dapat memperjelas kata-kata dari cerita pada komik, c) Menggunakan warna yang menarik dan terang sehingga siswa akan lebih termotivasi untuk membaca komik, d) Cerita pada komik sangat erat dengan kejadian yang dialami siswa sehari-hari sehingga mereka akan lebih paham dengan permasalahan yang mereka alami.

Seperti yang dikemukakan oleh Kustianingsari (2016), menyatakan bahwa:

Kelebihan Media Komik Digital antara lain : 1) Dipandang dari kelebihannya, komik dapat menarik semangat siswa dalam belajar dan mengajari siswa untuk menerjemahkan cerita ke dalam gambar sehingga siswa dapat mengingat sesuatu lebih lama. 2) Materi yang terdapat di dalam komik dapat menjelaskan keseluruhan cerita karena terdapat ilustrasi gambar yang dapat mempermudah siswa mengetahui bentuk atau contoh kongkrit mengenai maksud dari suatu materi. Dapat mengembangkan minat baca siswa dan salah satu bidang studi yang lain. 3) Komik digital yang berbentuk data elektronik bisa disimpan dalam bentuk digit atau byte, dan bisa ditransfer ke dalam berbagai macam media penyimpanan.

Dapat dilihat pada pemaparan di atas kelebihan dari media komik digital, sehingga apabila diintegrasikan nilai-nilai keislaman dalam pembelajaran melalui sebuah media bukan hanya akan memenuhi tuntutan perkembangan zaman modern yakni teknologi industry 4.0 tetapi juga dapat mengembangkan wawasan spiritual yang semakin mendalam dan mengembangkan pemahaman tentang islam dalam konteks kehidupan.

\section{KESIMPULAN}

Berdasarkan penjabaran yang telah dijelaskan di atas dapat dikatakan bahwa komik digital dengan mengintegrasikan nilai-nilai keislaman perlu dikembangkan sebagai media penunjang dalam proses pembelajaran biologi.

\section{SARAN}

Saran yang dapat diberikan dari penelitian pengembangan ini adalah sebagai berikut: 1) Dalam penelitian pengembangan sebaiknya dibuat jadwal target penyelesaian media secara terperinci untuk setiap harinya. Hal ini dapat menghindari kesalahan yang timbul akibat pembuatan media yang terburu-buru. 2) Untuk penelitian pengembangan selanjutnya, pembuatan media sebaiknya dikerjakan langsung oleh peneliti sehingga diperoleh hasil yang sesuai dengan keinginan peneliti. 3) Media yang telah dihasilkan dapat diuji coba lagi pada beberapa sekolah dengan kelompok yang lebih besar agar produk yang dihasilkan dapat lebih representatif.

\section{DAFTAR RUJUKAN}

Herawati, Dera Dwi., Wahyuni, Dwi., dan Prihatin, Jekti. 2014. Penerapan Model Pembelajaran Kooperatif Tipe NHT (Numbered Head Together) dengan Media Komik pada Materi Pengelolaan Lingkungan Guna Meningkatkan Motivasi dan Hasil Belajar. Jurnal Pancaran, Vol. 3, No. 3, Hal 7382, Universitas Jember.

Karwono. 2012. Belajar dan Pembelajaran. Jakarta: Raja Grafindo Persada.

Muspiroh, N. 2013.Integrasi Nilai Islam dalam Pembelajaran IPA. Jurnal Nilai Islam. Vol. XXVIII. No. 3.Institut Agama Islam Negeri Syekh Nurjati Cirebon.

Nurinayati, Fitri; Sartono; Nurmasari; dan Dian Evriyani. 2014. 
Pengembangan Media

Pembelajaran Dalam Bentuk

Komik Digital Pada Materi

Sistem Imun di SMA Negeri 13

Jakarta. Jurnal BIOSFER, Vol.

VII, No. 2.

Rusman. 2017. Belajar dan

Pembelajaran Berorientasi

Standar Proses Pendidikan.

Jakarta: Kencana.

Sudiyanto., Yuliana., dan Siswandari. 2017. Pengembangan Media Komik Digital Akutansi pada Materi Menyusun Laporan Rekonsilasi Bank untuk Siswa SMK. Jurnal Pendidikan dan Kebudayaan, Vol. 2, Nomor 2. Universitas Sebelas Maret Surakarta.

Wardani, Tri Kurnia. 2012. Penggunaan Media Komik dalam Pembelajaran Sosiologi pada Pokok Bahasan Masyarakat Multikultural. Jurnal KOMUNITAS. Vol.4. No.2. Universitas Negeri Semarang. 